\title{
Effects of Sex Steroids and Calcium on the Uterine Contraction
}

\author{
Shigeru TOMITA \\ Department of Obstetrics and Gynecology, Kyoto Prefectural University of \\ Medicine, Kyoto, Japan (Director : Professor Gen-ichi Tokuda)
}

\section{INTRODUGTION}

Many studies have been made on the mechanism of regulating uterine muscle activities. But the question of how uterine functions are controlled by hormones and ions has not yet been clearly answered. It has been widely accepted that the membrane resting potentials regulate mechanical and electrical activities of the uterus, i.e. the myometrial activities are inhibited when the membrane resting potentials are out of a certain firing range. But the results of a recent investigation failed to confirm the difference of resting potential levels between stimulated and inhibited conditions. Moreover, the mechanism is further complicated by the effects of sex steroids which are not the same in vitro as they are in vivo.

Bivalent ions, especially calcium, have recently been thought to play very important roles in the uterine muscle activities. Calcium is now accepted to be the main ion to evoke spikes.

This study was made to determine and compare the effects of estradiol-17 $\beta$ and progesterone in vivo and in vitro and of calcium on the activities of rat the myometrium.

\section{MATERIAL AND METHODS}

Wistar strain pregnant and nonpregnant estrus female rats were used. Pregnant rats were divided into three groups; 1) group 1 received estradiol-17 $\beta 10 \mu \mathrm{g}$ daily for three days as estrogen-dominant, 2) group 2 received progesterone $1 \mathrm{mg}$ daily for three days as progesterone dominant, and 3) group 3 was untreated. Experiments were performed with the isolated uteri on the 21 st day of gestation.

Calcium content of the myometrial cells was measured with Yanagisawa's method. The tension of the myometrium was measured with a force-displacement transducer, Nihonkoden SB-1T. Action potentials were recorded with needle electrodes, and resting potentials with glass micro-electrodes.

The difference in contractile effects between oxytocin, acetylcholine and sparteine sulfate was investigated by perfusing the nonpregnant myometrium in Ca-free Tyrode solution at $37.0^{\circ} \mathrm{C}$ and normal Tyrode solution at $22.0^{\circ} \mathrm{C}$.

\section{RESULTS AND COMMENT}

Calcium content of the pregnant rat myometrium decreased gradually when suspended in Ga-free Tyrode solution. Total calcium content decreased more rapidly in the progesterone-dominated myometrium than in the estrogen dominated myometrium. But 
calcium ion content of the progesterone-dominated myometrium remained fairly stable in comparison with that of the estrogen-dominated myometrium. Thus it is concluded that calcium is more loosely bound in the progesterone-dominated myometrium than in the estrogen-dominated myometrium. (Fig. 1, Table 1)

Contractions and action potentials well synchronized in the estrogen-dominated myometrium, but were asynchronous in the progesterone-dominated uterus. When uterine strips were suspended in Ca-free Tyrode solution, all action potentials and contractions disappeared. Activities of the progesterone-dominated uterus increased transiently shortly after being perfused with Ca-free Tyrode solution. These increased activities are understood to appear as the membrane potential passes through the "critical" range. (Fig. 2, Fig.3)

Membrane resting potential of the estradiol treated myometrium showed $46.5 \mathrm{mV}$, whereas that of the progesterone treated myometrium revealed $48.7 \mathrm{mV}$, and that of the untreated myometrium showed $39.5 \mathrm{mV}$. When perfused with Ca-free Tyrode solution, these values depolarized to the steady values of $35.0,33.6$ and $26.4 \mathrm{mV}$, respectively. (Fig. 4, Table 2)

Uterine electrical and mechanical activities were inhibited when suspended in Tyrode solution with estradiol and with progesterone $(0.1 \mathrm{mM} / 1$.). Membrane resting potentials measured in both media were 39.5 and $40.8 \mathrm{mV}$, respectively, showing no significant difference from the value in normal Tyrode solution. (Table 3) Therefore, the validity of the so-called "critical range" hypothesis is questioned.

When suspended in Ca-free Tyrode solution, the contractile effect of sparteine sulfate was least potent of the three agents (oxytocin, acetylcholine, and sparteine sulfate). But in $22.0^{\circ} \mathrm{C}$ Tyrode solution no such discrepancy of contractile activities was demonstrated. (Fig. 5, Fig. 6) These data suggest that this inhibition in Ca-free media has something to do with endogenous acetylcholine.

\section{SUMMARY}

1) In Ca-free Tyrode solution calcium content of the myometrium dereased. Calcium was thought to be more loosely bound in the progesterone-dominated myometrium than in the estrogen-dominated myometrium.

2) Contractions and action potentials well synchronized in the estrogen-dominated myometrium, but were asynchronous in the progesterone-dominated myometrium.

3) Membrane resting potential of the untreated myometrium on the 21 st day of gestation was $39.5 \mathrm{mV}$. This value was hyperpolarized to $46.5 \mathrm{mV}$ in the estrogen-dominated myometrium and to $48.7 \mathrm{mV}$ in the progesterone-dominated myometrium.

4) Estradiol and progesterone in vitro inhibited uterine contractions, but did not alter the resting potential levels.

5) The contractile effect of sparteine sulfate was markedly inhibited in Ca-free Tyrode solution, but to a lesser degree in normal Tyrode solution at low grade temperature.

(pp. 1130 1138) 


\title{
子宮筋収縮に対する性ホルモンと Calcium の役割について
}

\author{
京都府立医科大学産婦人科学教室（主任 徳田源市教授）
}

富田慈

（昭和 43 年 3 月 25 日受付）

子宮筋収縮に及ぼす性ステロイドと Ca の影響を検討した。子宮筋の組織内 $\mathrm{Ca}$ 量の測定および機 械的, 電気的活性を調べた. progesterone は Ca と組織蛋白との結合を弱め, 活動電位を抑制し, 細 胞内静止電位を過分極させた。 estradiol は全く逆の結果を示した。両者とも in vitroでは収縮抑制を 示したか静止電位を変化させなかつた。乙れらのととより Ca 欠乏時, および estradiol あるいは progesterone による静止電位の変化の意義について検討した.

\section{緒 言}

平滑筋の収縮に関しては，古来さまざまな報告がなされているが，なお解明されていない点が多く残され ている，てとに子宮平滑筋は各種性ステロイドおよび下垂体ホルモンの複雑な支配を受けているという点に おいて，他の内藏平滑筋とおもむきを異にしている，Goto and Csapo $\left.(1959)^{14}\right)$ はウサギについて実験し， 妊娠時には子宮笳細胞内静止電位が増大してくるが, てれは主として progesterone の増量によるものであり, さらに estrogen もてれに関与するものであると報告した。すなわち, estrogen は静止電位を增大させて正 常活動に十分な電位とし, progesterone はさらにてれを增大させてかえつて過分極を起てさせ，したがつて 子宮筋収縮を抑制するものであると結論している。しかしてれ対しては反対の報告もなされている ${ }^{23)}$.ま た estrogen もその投与量によつてはかえつて收縮を抑制するという報告もみられる゙4).さらに estrogen は in vitro 亿作用させた時には progesterone よりも強力な子宮筋収縮抑制作用を持つているとの報告もあり 1)31)，乙れら性ステロイドの子宮筋に対する作用には，いまだ明らかにされていない面が多い.

子宮筋に及ぼす Ca をはじめとする 2 価イオンの作用は, 最近著しく注目されつつある. 1951年 Hodgkin and Huxley ${ }^{15)}$ のとなえた神経興奮に関する「Na 学説」はそのまま平滑筋の興奮機構の説明にも適用でき るとされていたが，つぎつぎと「Na なしの興奮」という現象が発見されてきた．そのうちでも Fatt and Ginsborg $^{10)}$ は甲㱿類の筋線維の活動電位が Ca などの 2 価イオンの移動のため起しるものであろうと推定 し, さらに野々村, 大橋 ${ }^{30}$ は平滑筋の活動電位も Ca スパイクである可能性を示した.

てのように子宮平滑筋に対して estrogen および progesterone, ならびに Ca はきわめて重要な役割をは たしているようであるが，その作用機序はいまだ不明の点があるようである。てれらを解明するために子宮 筋内 $\mathrm{Ca}$ 量, 子宮筋収縮波形, 活動電位, ならびに細胞内静止電位の面より検討した.

\section{実験材料および実験方法}

\section{A. 実験材料}

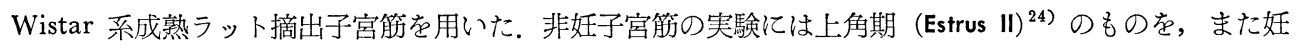
娠子宮の実験には妊娠第21日のものを用いた，妊娠ラットには妊娠第18，19，および20日の 3 日間 progesterone lmg.，あるいは estradiol-17 $\beta 10 \mu \mathrm{g}$. を筋注した。

\section{B. 実験方法}

まず無 Ca Tyrode 液中に妊娠ラット摘出子宮筋をひたし，その子宮筋内 $\mathrm{Ca}$ 量の変動を測定した。測 
定には血液, 妊娠内容および灌流液を可及的に無灰ろ紙で除き，1\% NaCN 液を加えて homogenate とし， 約 1,000G 10分間遠沈し，その上清について柳沢氏法 ${ }^{39} に よ り$ 測定した.

子宮筋収縮を日本光電製 strain gauge (SB-1T) により増幅記録した。

子宮筋の活動電位を双極套管針電極を用いた細胞外誘導法によつて記録した。電極は日本光電製で $1 / 4$ 皮 下針の中に電極を封入したもので，てれょり日本光電製の生物電気用前置増幅器（APB-20），および高感度 增幅器 $(\mathrm{ADH}-2)$ を介して直記式オッシログラフ (W1-180) によつて記録した.

細胞内静止電位をガラス微小電極より微小電極用前置増幅器 (日本光電製 $\mathrm{MZ}-2 \mathrm{~B}$ ) を通じてブラウン管 オッシロスコープ (VC-10) に導き, 連続撮影装置 (PG-1B) により撮影した。微小電極は外径 $2 \mathrm{~mm}$. 尖 端 $0.5 \mu$. 以下の硬質ガラス管に $3 \mathrm{M} \mathrm{KCl}$ 液を満たして電極保持器に固定し, 銀一塩化銀電極を通じて前置 増幅器に導いた。またときには子宮筋収縮や動摇による微小電極の破損を防ぐために直径約 $0.2 \mathrm{~mm}$. 長さ 約 $2 \mathrm{~cm}$.の銀線を使用し flexible microelectrode を作製した。電気抵抗 $10 \mathrm{M} \Omega$ から $20 \mathrm{M} \Omega$ の電極を使 用した。また穿刺部位は胎盤非付着部とした。

灌流に使用した Tyrode 液の組成は $\mathrm{mM}$ 濃度で $\mathrm{NaCl}$ 134.0, $\mathrm{KCl} 4.6, \mathrm{MgCl}_{2} 0.1, \mathrm{CaCl}_{2} 1.2, \mathrm{NaHCO}_{3}$ 16.3, $\mathrm{NaH}_{2} \mathrm{PO}_{4}$ 1.1, dextrose 7.8, であり，pH7.2〜7.6 とした。また使用した無 Ca Tyrode 液は正常 Tyrode 液より $\mathrm{CaCl}_{2}$ のみを除いたものであり, 高 $\mathrm{Ca}$ Tyrode 液は $\mathrm{CaCl}_{2}$ を $12 \mathrm{mM}$. $/ 1$. 亿増加せしめた ものである. 灌流 Tyrode 液は $37.0 \pm 1.0^{\circ} \mathrm{C}$, また低温実験では $22.0 \pm 0.5^{\circ} \mathrm{C}$. 亿保ち, 空気で飽和した。

\section{実 験 成 績}

\section{A. 無 Ca Tyrode 液中の妊娠子宮筋内 Ca 量の変動}

摘出子宮筋を無 $\mathrm{Ca}$ Tyrode 液につけ, その灌流前, 灌流開始 7 分後, 30 分後にその組織内 $\mathrm{Ca}$ 量の変動 を胎盤付着部之非付着部とに分けて測定した。

胎艋非付着部は progesterone 処置群では estradiol 処置群のそれよりも著明に速く, また大量に組織内 総 $\mathrm{Ca}$ 量の減少が認められた。しかし progesterone 処置群では透析性 Ca 量の減少は estradiol 処置群に くらべて軽度で, その值はほぼ一定であつた。すすおち progesterone 処置群の組織内総 Ca 量の減少は大 部分結合型 $\mathrm{Ca}$ 量の減少によつて起てつていると考えられる. てれに対して estradiol 処置群では総 $\mathrm{Ca}$ 量 の減少速度は遅く，また軽度であるにもかかわらず，透析性 $\mathrm{Ca}$ 量の減少が比較的著明であるから，総 $\mathrm{Ca}$ 量の減少は大部分透析性 Ca の減少によつて起とつていると考えられる.

胎盤付着部では，Ca 量の減少が認められるが，両ホルモン処置群間に有意の差は認められなかつた。

(Fig. 1, Table 1)

Table 1. Calcium content of estradiol-17 $\beta$ treated and progesterone treated pregnant rat myometrium, suspended in Ca-free Tyrode solution

\section{Calcium Content}

Antiplacental site

\begin{tabular}{l|l|r|r|r}
\hline \multirow{2}{*}{} & & \multicolumn{3}{|c}{$\begin{array}{l}\text { Time in Ca-free } \\
\text { Solution }\end{array}$} \\
\cline { 3 - 5 } & & \multicolumn{1}{c}{ Tyrode } & \multicolumn{1}{c}{7} & $30 \mathrm{~min}$. \\
\hline \multirow{2}{*}{ Progesterone } & $\mathrm{Ca}$ & 16.9 & 13.1 & 11.2 \\
& $\mathrm{Ca}^{++}$ & 3.0 & 2.5 & 2.2 \\
\hline \multirow{2}{*}{ Estradiol } & $\mathrm{Ca}$ & 16.6 & 14.8 & 12.5 \\
& $\mathrm{Ca}^{++}$ & 3.9 & 3.2 & 3.1 \\
\hline
\end{tabular}

Fig. 1. Calcium content of antiplacental site of estradiol-17 $\beta$ treated and progesterone treated pregnant rat myometrium, suspended in Ca-free Tyrode solution

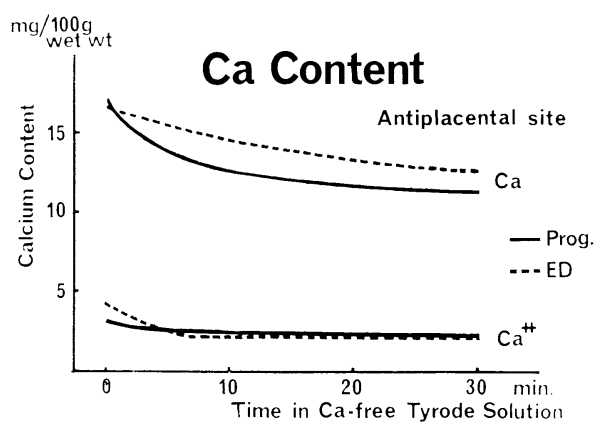




\section{B．妊娠子宮筋収縮および活動電位に及ぼす外液 $\mathrm{Ca}$ の影響}

\section{Estradiol 処置群}

正常 Tyrode 液中では良く同期するスバイク放電群が認められ，また放電群の発現も規則正しかつた。 さらに放電群と筋収縮との同期性もよく保たれていた，灌流液を無 Ca Tyrode 液に換えると放電群は次第 に滥弱となり，同時に筋収縮も弱くなつて，ついは両者とも消失した。灌流液を高 Ca Tyrode 液に換え る之，活動電位および筋収縮は正常 Tyrode 液の場合に比べてスパイク放電群の同期性が㭧く，また放電 群之筋収縮との同期性も悪くなるのが浔められた。(Fig. 2)

\section{Progesterone 処置群}

正常 Tyrode 液中では estradiol 処置群に比べ，スパイク放電群の同期州汭㴗く，放電群の発現も不規 則であつた。また放電群と筋収縮との同期も悪いようである。無 Ca Tyrode 淮で灌流をすると, 灌流開始 直後に一時スパイク放電群の同期性がやや良くなり，放電群と筋収縮との同期も良くなるが，時間の経過と ときに次第に活動電位抢よび筋収縮が弱くなり，やがて消失した，高 Ca Tyrode 液にて灌流すると正常 Tyrode 液の場合に比べ，スパイク放電群の持続時間および筋収縮時間は長くなる傾向にあり，同期性の改 善が浔められた。(Fig. 3)

Fig. 2. Action potentials and contraction curves of estradiol-17 $\beta$ treated pregnant rat myometrium in (1) normal Tyrode solution, (2) Ca-free Tyrode solution, and (3) $\mathrm{Ca} 12 \mathrm{mM}$ Tyrode solution

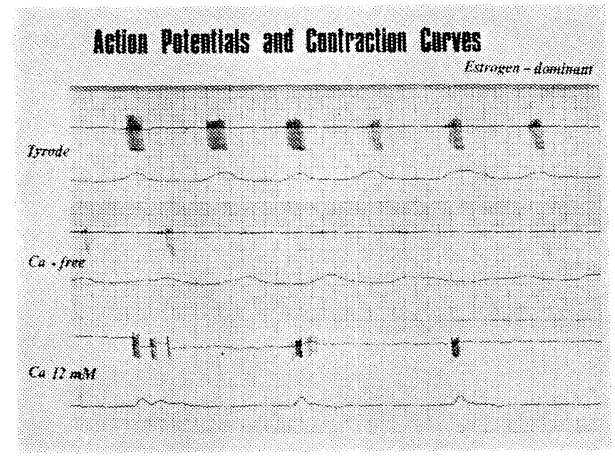

Fig. 3. Action potentials and contraction curves of progesterone treated pregnant rat myometrium in (1) normal Tyrode solution, (2) Ca-free Tyrode solution, and (3) Ga $12 \mathrm{mM}$ Tyrode solution

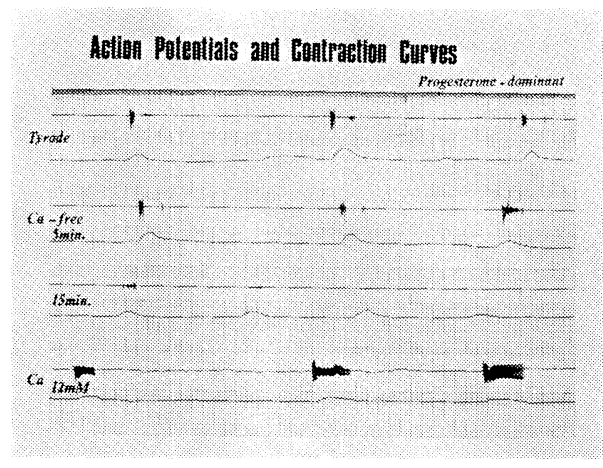

\section{C． 妊娠子宮筋細胞内静止電位に及ぼす外液 Ca の影響}

\section{Estradiol 処置群}

静止電位は正常 Tyrode 液中では，平均 $46.5 \pm 0.6 \mathrm{mV}$. である。無 Ca Tyrode 液で30分間灌流すると $35.0 \pm 1.9 \mathrm{mV}$ ．まで脱分極を起こしてきた。また高 $\mathrm{Ca}$ Tyrode 液で30分間灌流すると $50.2 \pm 1.1 \mathrm{mV}$.と高 くなり，過分極を起てすようになつた。

\section{Progesterone 処置群}

静止電位は正常 Tyrode 液中では $48.7 \pm 0.3 \mathrm{mV}$. と estradiol 処置群より少し過分極に傾くようである. 無 Ca Tyrode 液中では $33.6 \pm 2.0 \mathrm{mV}$. まで脱分極するが，高 Ca Tyrode 液中では $46.6 \pm 2.0 \mathrm{mV}$.までの 脱分極をすることが認められた。

\section{3. 無処置群}

静止電位は正常 Tyrode 液中では $39.5 \pm 0.5 \mathrm{mV}$. であり，無 Ca Tyrode 液中では $28.4 \pm 1.8 \mathrm{mV}$., 高 Ca Tyrode 液中では $33.4 \pm 1.6 \mathrm{mV}$. の佔を得た。(Fig. 4, Table 2) 
Table 2. The effect in vivo of estradiol-17 $\beta$ and progesterone on the membrane resting potential of pregnant rat myometrium in (1) normal Tyrode solution, (2) Ca-free Tyrode solution, and (3) Ga $12 \mathrm{mM}$ Tyrode solution

Membrane Potential $(\mathrm{mV})$

\begin{tabular}{l|l|l|l}
\hline & Tyrode & Ga-free & Ca 12mM \\
\hline \hline Estradiol & $46.5 \pm 0.6$ & $35.0 \pm 1.9$ & $50.2 \pm 1.1$ \\
Progest. & $48.7 \pm 0.3$ & $33.6 \pm 2.0$ & $46.6 \pm 2.4$ \\
Control & $39.5 \pm 0.5$ & $28.4 \pm 1.8$ & $33.4 \pm 1.6$ \\
\hline \multicolumn{3}{|c}{ Mean 1 S.E. }
\end{tabular}

Fig. 4. The effect in vivo of estradiol-17 $\beta$ and progesterone on the membrane resting potential of pregnant rat myometrium

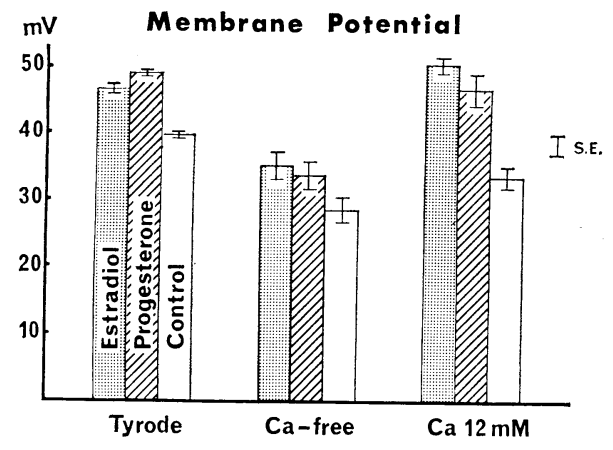

\section{D. 妊娠子宮筋細胞内静止電位に及ぼす in vitro の estradiol-17 $\beta$ および progesterone の影響}

estradiol および progesterone が in vitro に子宮筋の運動を抑制するととはすでに報告されているが゙ 18)19)31)，Ga 欠乏の子宮筋収縮抑制が，てのような性 steroid による抑制と細胞内電位の面からみて異なる かどうかを検討した。

そこで estradiol-17 $\beta$ ，あるいは progesterone を ethanol で溶解し, 0.1mM./1. の割合に Tyrode 液に加 えた後にろ過した液を使用して灌流した。 その液の ethanol 濃度は0.2\%であつた。なお対照にも同濃度の ethanol を加えた，その液による細胞内静止電位の 変化について灌流開始前と開始後30分の值を比較し た.

\section{Estradiol 作用群}

細胞内静止電位は平均 $39.5 \pm 0.7 \mathrm{mV}$. と対照との 間に全く差異を認めなかつた。 また活動電位は記録 不可能であつた. (Table 3)

\section{Progesterone 作用群}

静止電位は平均 $40.8 \pm 1.2 \mathrm{mV}$. と対照との間に差 異は認められなかつた。しかし活動電位は時に記録 することができた. (Table 3)

E. Oxytocin, acetylcholine および sparteine sulfate の非妊子宮筋収縮作用に及ぼす Ca

Table 3. The effect in vitro of estradiol-17 $\beta$ and progesterone $(0.1 \mathrm{mM}$ per one litter of Tyrode solution) on the membrane resting potential of pregnant rat myometrium

\section{Membrane Potential}

The Effect of Steroids in vitro

\begin{tabular}{l|r|r|c}
\hline & Mean & S.E. & S.D. \\
\hline \hline Estradiol & 39.5 & 0.69 & $3.9 \mathrm{mV}$ \\
Progesterone & 40.8 & 1.20 & $4.5 \mathrm{mV}$ \\
Control & 39.5 & 0.54 & $2.6 \mathrm{mV}$ \\
\hline
\end{tabular}

\section{欠乏および低温の影響}

\section{Ca 欠乏の影響}

無 Ca Tyrode 液に oxytocin $10^{-4}, 10^{-3}, 10^{-2} \mathrm{U} . / \mathrm{ml}$, acetylcholine $10^{-6}, 10^{-5}, 10^{-4} \mathrm{gm} . / \mathrm{ml}$, sparteine sulfate $10^{-4}, 10^{-3} \mathrm{gm} . / \mathrm{ml}$. の割合に加え，それぞれ子宮筋収縮波形を記録し，その振幅を求めた。正常 Tyrode 液中での oxytocin $10^{-4} \mathrm{U} . / \mathrm{ml}$., acetylcholine $10^{-6} \mathrm{gm} . / \mathrm{ml}$., あるいは sparteine sulfate $10^{-4} \mathrm{gm} . / \mathrm{ml}$. の溶液中における収縮波形の振幅を100として, それぞれの薬剤の各濃度における振幅を比較した。

sparteine sulfate は無 Ca Tyrode 液中では著明に収縮は抑制され，濃度を高くしてもほとんど反応し ないにかかわらず，oxytocin および acetylcholine の場合にはその収縮は弱いが，濃度を高くすると反応 性がかなり高くなることが認められた。（Fig. 5) 
Fig. 5. Uterine contractions in Ca-free Tyrode solution induced by different concentrations of (1) oxytocin, (2) acetylcholine, and (3) sparteine sulfate

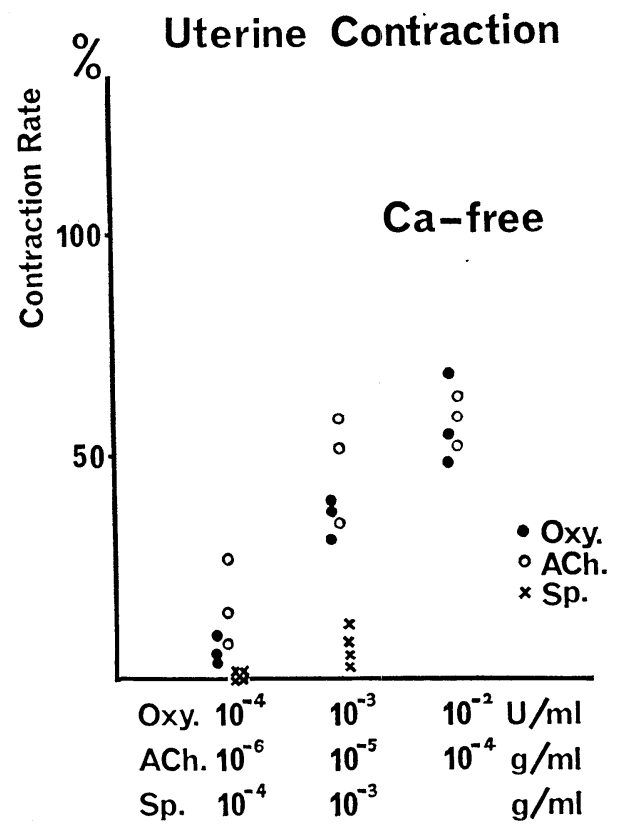

Fig. 6. Uterine contractions in $22.0^{\circ} \mathrm{C}$ Tyrode solution induced by different concentrations of (1) oxytocin, (2) acetylcholine, and (3) sparteine sulfate

\section{Uterine Contraction}

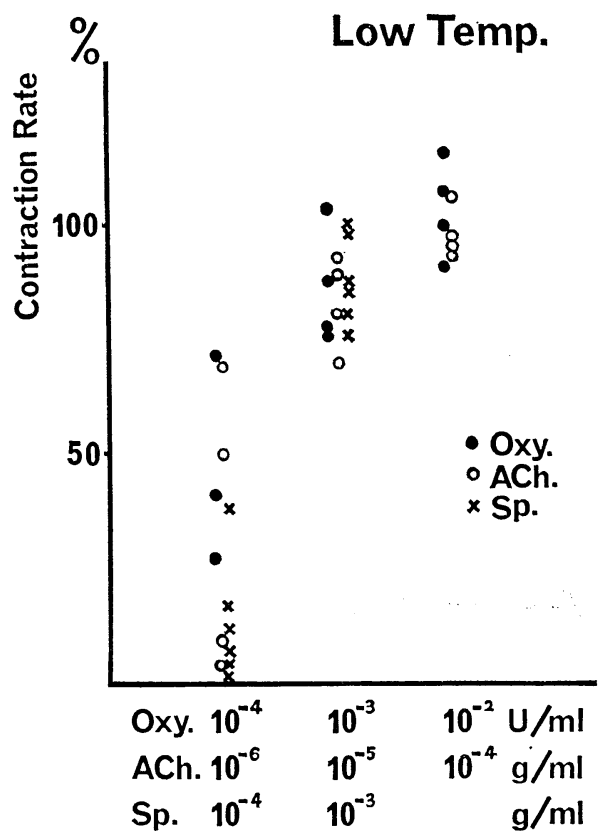

\section{2. 低温の影響}

Tyrode 液を $22.0 \pm 0.5^{\circ} \mathrm{C}$. に保ち, 同様の実験を行なつた. この実験で特徴的なととは oxytocin, acetylcholine, および sparteine sulfate の 3 者の間の抑制像に差がみられなかつたてとであり，Ga 欠乏実験の ように sparteine sulfate だけが著明に抑制されるというような像は認められなかつた（Fig. 6)

\section{総括および考案}

\section{A. Ca 欠之による子宮筋収縮抑制について}

興奮と収縮の関連性について Ca が中心的な役割をはたしていることは今や多くの人が認めているとてろ である，外液を無あるいは低 Ga Tyrode 液に置換すると収縮および活動電位が消失してくるてとはすでに 1958年に Coutinho and Csapo ${ }^{3)}$ が報告している。 それ以来 Goto and Csapo (1958) ${ }^{13)}$, Marshall and Csapo $(1961)^{28)}$, Kuriyama and Csapo $(1961)^{26)}$ らによつて同様な報告が次々となされてきた. また外液を無ある いは低 Ca の状態にした時に収縮および細胞内静止電位に及ぼす estrogen および progesterone の効果につ いても Goto and Csapo (1959) ${ }^{14)}$ 以来種々の報告がみられる.すなわち, Goto and Csapo ${ }^{14)}$ の報告によれ ば，無 Ca Tyrode 液で子宮筋を灌流すると estrogen 処置群では約10分後に細胞内静止電位は $30 \mathrm{mV}$. 以 下の一定した值にまで脱分極を起てすが， progesterone 処置群では一時的な脱分極を起てすだけで，約15分 後にはもとの值まで再分極を起こすという。しかし，ての progesterone 処置群で起てるといわれていた 再分極は， sucrose gap method を用いた Marshall and Csapo $(1961)^{28)}$ の実験で否定されている。また 
Coutinho and Csapo $(1958)^{3)}(1959)^{4)}$ は無 Ca Tyrode 液中での子宮筋刺激実験によると, progesterone 処置群の方が疲労が少ないととを認めた。てれらの実験よりCoutinho and Csapo $(1958)^{3)}$ は progesterone 優勢のもとでは子宮筋細胞の Ca の結合力か漒いのか，あるいは興奮性が失なわれるまでに estrogen 優勢 の場合より多量の $\mathrm{Ca}$ が放出されるのではないかと示唆した.

本実験はまずての点を明らかにするために娃娠末期ラットを estradiol-17 $\beta$ あるいは progesterone で処 置した後に無 Ca Tyrode 液中で灌流し，その細胞内 Ca 量の変動を測定した。 その結果 progesterone 処 置群の方がすみやかに総 $\mathrm{Ca}$ 量の減少が起とり，しかも結合型 $\mathrm{Ca}$ 量の減少が著しいてとから， Ca の結合 力は estradiol 処置群に比べて弱く，すみやかに Ca が放出され，興奮性が維持されるのであろうという結 果を得た。てれに対して estradiol 処置群では, 総 Ca 量の減少速度は progesterone 処置群に比へて遅く, しかも遊離 $\mathrm{Ca}$ 量の減少がはやいととから，Ca の結合力が強く，遊離が困難であろうという結果を得た。 また本実験の総 Ca 量の值は細田 (1965) ${ }^{16)}$, Casteels and Kuriyama (1965) ${ }^{5)}$ の值より高值であるが, Cibils and Schweid $(1966)^{6)}$ とほぼ同じ值を示した。

性ステロイドの子宮筋に及ぼす作用については種々の報告がなされている，細胞外誘導法により德田 $(1953)^{36)}$ はウサギ子宮の活動電位は発情期に頻度および振幅が増大し， estrogen 投与時の像と同様になり， また発情間期には活動電位は減少し，発情期のウサギに progesterone を投与すると発情期と発情間期の中 間の状態を示したと報告した. Jung (1956) ${ }^{20)}$ によれば去勢ラットに estradiol benzoate を投与すると活 動電位の頻度および振幅の増大と, スパイク放電の同期化が起てり, progesterone 投与時には逆の結果を得 た. また高田 $\left.(1960)^{35}\right)$ は去勢ウサギに estradiol を投与すると活動電位の集団化と均一化が起こることを 認めている，そしててれは子宮笳活動の motor unit の拡大と各細胞の興奮の同期化によるものであり， progesterone 投与時には motor unit は縮小し，同期化が悪くなると報告した。また鈴村 $(1965)^{34)}$ は去勢 ウサギによる実験で estrogen 投与時には投与量が增加するにしたがつて電気的活性の上昇を認めたが, estradiol $120 \mu \mathrm{g}$. 以上の大量投与をすると活性の低下が起こることを認めた。 また progesterone 投与群で は電気的活性が低下するととを認めた。

一方，微小電極法による細胞内電位記録は 1954年 Woodbury and Mclntyre ${ }^{38)}$ が初めて子宮筋に応用して 以来，多くの報告がなされている．Goto and Csapo (1959) ${ }^{14)}$ はウサギの娃娠経過にしたがつて細胞内静 止電位が変化するが, 胎艋非付着部では妊娠後半期においては $45 \mathrm{mV}$. 程度であり, 末期になると数 $\mathrm{mV}$. 增 大してくる．胎盤付着部では妊娠後半期には $50 \mathrm{mV}$. であり非付着部より大である.しかし末期になると60 $\mathrm{mV}$. '程度まで增大するが, 分婏直前になるとすみやが減少し, 非付着部と同じ值になつたと報告した。 さらに娃娠第25日のウサギについて, 胎盤よりの距離と静止電位との関係について述べ, 胎艋よりの距離が へだたるほど静止電位が減少するてとを認めた。そしててれらの結果から, 胎盤より分泌される estrogen および progesterone によつててのような静止電位の変化が起てつてきたものであると報告した。 てれら estrogon および progesterone の作用は, Marshall (1959) ${ }^{27)}$ の去勢ラットの実験隹よつて裏付けられた. すなわち，去勢ラットの子宮筋細胞内静止電位は $35.2 \mathrm{mV}$. であるが， $6.0 \mu \mathrm{g}$. の estradiol benzoate を 5 日間投与した後には $57.6 \mathrm{mV}$. まで分極を起しし，律動的収縮およびスパイク放電が出現するととを認めた。 またそのうえにさらに progesterone $12 \mathrm{mg}$. を 5 日間投与すると，静止電位は $63.8 \mathrm{mV}$. まで過分極を起て し，収縮および活動電位の消失を認めたと報告した。同様の報告は数多く行なわれ28899322)，Csapo $(1954)^{7)}$ の “progesterone block” 説が強く支持された.

しかし Jung (1962) ${ }^{21)}(1965)^{22)}$ および Kao and Nishiyama (1964) ${ }^{23)}$ らはての progesterone block に 対して反対の意見を持つている。すなおち, Jung は progesterone の興奮抑制が静止電位の上昇なしに起て るものであり, 細胞膜の Na の透過性に関係したものであると述べ, Kao and Nishiyama はウサギについ て両ステロイド投与時の静止電位の間に有意の差を認めないてとから, progesterone block に対して疑問を 述べた.

本実験においては，estradiol-17 $\beta$ あるいは progesterone を妊娠ラットに投与したてとが従来の報告と異 
なる点ではあるが， 細胞外誘導法では progesterone 処置群において同期性の悪いスパイク放電群を認め, また放電群と収縮との同期性も悪かつた。乙れに反して estradiol 処置群においては放電群の同期性も, 収 縮との同期性も良く，従来の報告に一致した結果を得た。また細胞内誘導法による静止電位については，両 ステロイド処置群においては無処置群に比べて著明な静止電位の上昇を認めたが, progesterone 処置群にお いて estradiol 処置群より過分極が起こる傾向が認められた。 そして無 Ca Tyrode 液で灌流を行なつた時 に, progesterone 処置群に一時的な電気的活性の上昇が認められたが，てれは細胞内静止電位の面よりみて おそらく脱分極を起てして行く過程において䦨值に達し，スパイク放電の立進が認められたものと解释され る.また高 Ca Tyrode 液中での動態も同様に過分極および脱分極を起とすようになるてとより説明しうる. 無処置群の細胞内静止電位の值を従来の報告と比較すると, Goto and Woodbury (1958) ${ }^{122}$, West and Landa $(1956)^{37)}$ および中川 $(1966)^{29}$ とほぼ同值を示し, Kuriyama and Csapo $(1961)^{26)}$ よりやや低值を示 した.

\section{B. Estradiol および progesterone の in vitro における子宮筋収縮抑制について}

estradiol は一般に in vivo そおいては子宮筋収縮を促進すると考光られているが， in vitro では反対に 抑制的に働くてとがすでに 報告されている18825331)，そしてその機序は不明であるが， Saldivar and Melton $(1966)^{31}$ はこのととは脱分極によるものであろうと示唆した. しかし Kumar et al. (1964) ${ }^{25)}$ によると 卜子宮筋における実験では，estradiol は in vitro で細胞内静止電位には影響を与えないが，収縮を抑制す ると報告した。

また progesterone の in vitro における抑制についても報告がなされている ${ }^{1925) 26(28) 311 . ~ M a r s h a l l ~ a n d ~}$ Csapo $(1961)^{28)}$ の sucrose gap method ${ }^{33)}$ による研究では $10 \mu \mathrm{g} . / \mathrm{ml}$. の progesterone を加えた Tyrode 液で灌流すると 30 分後にはすべての活動電位および収縮は消失するが，乙の時細胞内静止電位は $3 \sim 5 \mathrm{mV}$. 過分極を起てしていると報告した。 また Kuriyama and Csapo (1961) ${ }^{26)}$ の微小電極法による実験でもわず かながら過分極を認めた。また Kumar et al. (1964) ${ }^{25)}$ も過分極が起こることを認めた。 さらに Saldivar and Melton (1966) ${ }^{31)}$ は 5 対の銀一塭化銀電極による細胞外誘導法により，従来いわれていた電気的活性と 機械的活性との非同期性の存在を否定した。

本実験においても estradiol-17 $\beta$ および progesterone による収縮の抑制を認め，従来の報告と一致した。 しかし estradiol および progesterone ともに細胞内静止電位に対しては何等の影響を与えていないてとは 従来の報告と異なつている.

従来, 細胞内静止電位が収縮を支配するという考方方が多くの報告によつてなされてきた．しかしての静 止電位の変化なしに起とる収縮の抑制という問題，すなわち，子宮筋細胞内静止電位の変化は細胞膜内外の イオン分布の単なる結果にすぎず，興舊性を規定するものでないらしいといら問題を提起するものと考えら れる，要するに収縮を支配する機序にはいろいろの要素があり，単に静止電位だけの問題ではないと考えら れる。

\section{C. 子宮筋収縮物質とその抑制について}

oxytocin と sparteine sulfate の子宮筋収縮に及ぼす作用機序のちがいについてはすでにいくつかの報告 がある1117).すすなわち, sparteine sulfate は内因性 acetylcholine と無関係であるのに反して, oxytocin は acetylcholine と貯蔵蛋白および受容体との結合促進作用を持つ点が作用機序のちがいである。

さらに本実験において，Ca 欠乏によつて sparteine sulfate による収縮が一番著明に抑制された，てれら のことから，Ca 欠乏の収縮抑制機序に acetylcholine が関与しているのではないかと考觉られる．これに 反して，低温では sparteine sulfate は oxytocin および acetylcholine と同様の抑制を受けるが，てれは 低温による抑制が非特異的であり，内因性 acetylcholine の関与がないためと解釈される。

\section{結語}

ラット摘出子宮筋を用い, 子宮筋内 $\mathrm{Ca}$ 量, 子宮筋収縮波形, 活動電位, および細胞内静止電位の面より 
Ca の影響を検討した。 また性ステロイドの in vivo および in vitro の影響についても検討した.

1) 組織内総 $\mathrm{Ca}$ 量は胎艋非付着部において, estradiol 処置群では $16.6 \mathrm{mg} . / \mathrm{gm}$. 湿重量, progesterone 処置群で $16.9 \mathrm{mg}$. $/ 100 \mathrm{gm}$. 湿重量と著差を認めなかつたが, 無 Ga Tyrode 液で灌流すると progesterone 処置群の方がすみやかに減少を起とし，さらに progesterone 処置群の方が Ca と組織蛋白との結合がゆる やかであつた。

2）活動電位と収縮波形の同期性については，estradiol 処置妊娠ラットでは良い同 期性を示したが， progesterone 処置群では同期性が悪かつた。また無 Ca Tyrode 液中では活動電位わよび収縮は両者とも 消失したが， progesterone 処置群においては一過性に興奮性の促進が認められた。

3）妊娠第 21 日のラット子宮筋細胞内静止電位は, 無処置群では平均 $39.5 \mathrm{mV} .$, estradiol 処置群では $46.5 \mathrm{mV}$., progesterone 処置群では $48.7 \mathrm{mV}$. であり, 無 Ga Tyrode 液中では, それぞれ $28.4 \mathrm{mV} ., 35.0$ $\mathrm{mV}$. および $33.6 \mathrm{mV}$. まで脱分極が起てつた。また高 Ga Tyrode 液中では，それぞれ $33.4 \mathrm{mV} ., 50.2 \mathrm{mV}$, および $46.6 \mathrm{mV}$.を示した。

4）妊娠第21日の無処置ラット子宮筋を $0.1 \mathrm{mM} . / 1$. の割合に estradiol-17 $\beta$ あるいは progesterone を加 えた Tyrode 液で灌流すると，いずれも収縮および活動電位は抑制されたが，その細胞内静止電位は estradiol 加 Tyrode 液中で平均 $39.5 \mathrm{mV}$., progesterone 加 Tyrode 液中では $40.8 \mathrm{mV}$. でともに正常 Tyrode 液中の值と差異を認めなかつた。

5) oxytocin, acetylcholine および sparteine sulfate について, 外液を無 Ca Tyrode 液にした時, sparteine sulfate は一番著明に収縮作用の抑制を受けたが，外液を低温にした時の 抑制には 3 者間に差異 を認めなかつた。

6）乙れらの結果より，細胞内静止電位の面からだけでは説明のつけ難い子宮筋の収縮機構てついて考察 を加えた。

稿を終わるに臨み，終始御想篤な御指導と御校閲を賜わつた恩師德田源市教授並びに井上正二助教授に墚 甚なる謝意を捧げるとともに，種々御教導を睗わつた本学生理学教室岩瀬善彦教授，内田孝助教授に厚く感 謝する。また常に適切な御助言を睗わつた杉原養一助手はじめ教室諸学兄に澡く感謝の意を捧げる。

なお, 本論文の要旨の一部は第 13 回日本内分泌学会西日本地方会, 第 35 回近畿産科婦人科学会総会, およ び第 9 回日本平滑筋学会総会において発表した.

\section{文献}

1) BARNAFI, L. and H. CROXATTO : Acta physiol. lat.-amer., $13: 26$, (1963)

2) BENGTSSON, L.P. : Amer. J. Obstet. Gynec., $74: 484$, (1957) $\quad 3)$ COUTINHO, E.M. and A.I. CSAPO : Biol. Bull., 115 : 334, (1958) 4 4) COUTINHO, E.M. and A.I. CSAPO : J. gen. Physiol., $43: 13$, (1959) $\quad$ 5) CASTEELS, R. and H. KURIYAMA : J. Physiol. (Lond.), 177 : 263, (1965) 6) GIBILS, L.A. and D.E. SCHWEID : Amer. J. Obstet. Gynec., 94 : 619, (1966) 7) CSAPO, A.I. : Amer. J. Anat., $98: 273$, (1956) 1 8) CSAPO, A.I. : Recent Progr. Hormone Res., $12: 405$, (1956) 9) CSAPO, A,I. : Progesterone and the Defence Mechanism of Pregnancy, 1st ed. (1961), 3, J. \& A. Churchill Ltd., London. 10) FATT, P. and B.L. GINSBORG : J. Physiol. (Lond.), $142: 516$, (1958) 11) 藤原慎吾 : 日産婦会誌, 17 :191, (1965) 12) GOTO, M. and J.W. WOODBURY : Fed. Proc., 17:58. (1958) 13) GOTO, M. and A.I. CSAPO : Biol. Bull., $115: 335$, (1958) CSAPO : J. gen. Physiol., $43: 455$, (1959) 15) HODGKIN, A.L. and A.F. HUXLEY : J. Physiol. (Lond.), $117: 500$, (1952)

16）細田澄之：日産婦会誌，17：191，(1965)

17) INOUE, M., S. FUJIWARA, Y. SUGIHARA, M. KO, T. OISHI, S. TOMITA, I. OTANI, 
Y. IWATA, K. SHINAGAWA and T. TATEIWA : J. Jap. obstet. gynec. Soc., $14: 228$, (1967) 18）井上正二，杉原養一，高基三，大石徹，富田慈：日内分泌会誌，43：1109，(1968） 19）井上正 二, 高基三：日内分必会誌, $43: 1113$ (1968) 20 J JUNG, H. : Pflügers Arch. ges. Physiol., $263: 427$, (1956) 21) JUNG, H. : J. Obstet. Gynaec. Brit. Cwlth, $69: 1040$, (1962) 22) JUNG, H. : Arch. Gynäk., $202: 14$, (1965) 23) KAO, C.Y. and A. NISHIYAMA : Amer. J. Physiol., $43:$ 455, (1964) 24）小山良修，中尾健：生体の科学，6:88，(1954) 25) KUMAR, D., T. WAGATSUMA, W.J. SUllivaN and A.C. BARNES : Amer. J. Obstet. Gynec., $90: 1355$, (1964) $\quad$ 26) KURIYAMA, H. and A.I. CSAPO : Endocrinology, $68: 1010$, (1961) 27) MARSHALL, J.M. : Amer. J. Physiol., $197: 935$, (1959) 28) MARSHALL, J.M.andA.I. CSAPO : Endocrinology, $68: 1026$, (1961) 29) 中川閏一：日産婦会誌, $18: 620$, （1966） 30）野々村禎昭, 大橋秀法：日薬理誌，61：81，(1965） 31） SALDIVAR, J. T. Jr., and G.E. MELTON, Jr.: Amer. J. Physiol., $211: 835$, (1966) 32 SCHOFIELD, B.M. : J. Physiol. (Lond.), $138: 1$, (1957) 33) STÄMPFLI, R. : Experientia (Basel), $10: 508$, (1954) 34）鈴村正勝：第17回日産婦総会宿題報告要旨, (1965) 35) 高田守男 : 医学研究, $30: 3653$, （1960）36）徳田源市：日産婦会誌，5：727，(1953） 37) WEST, T.G. and J. LANDA：Amer. J. Physiol., $187: 333$, (1956) 38) WOODBURY, J.W. and D.M. MCINTYRE : Amer. J. Physiol., 177 : 355, (1954) 39）柳沢文正 : Ca および Mg の新定量法と代謝, 文光堂, (1955) 